Check for updates

Cite this: RSC Adv., 2018, 8, 40974

\title{
Synthesis and anti-glioblastoma effects of artemisinin-isothiocyanate derivatives $\dagger$
}

\begin{abstract}
Chan Myae Nyein,,$_{+}^{\text {abc }}$ Xiaolin Zhong,,$^{\mathrm{a}}$ Junfeng Lu, ${ }^{\mathrm{b}}$ Huijuan Luo, ${ }^{\mathrm{a}} \mathrm{Jiamin}$ Wang, ${ }^{\mathrm{a}}$ Simona Rapposelli, (D) ef Mingtao Li, ${ }^{d}$ Ying Ou-yang, ${ }^{9}$ Rongbiao $\mathrm{Pi}^{* \mathrm{bd}}$ and Xixin $\mathrm{He}$ (DD *a

A series of novel artemisinin (ART) derivatives containing an isothiocyanate (ITC) group were synthesized. All the compounds showed more potent anti-tumor effects than those of parent dihydroartemisinin (DHA) towards glioblastoma multiforme $\mathrm{U} 87$ in vitro. Among them, $5 \mathrm{~b}$ had the strongest cytotoxic activity which exerted its effects in a concentration-dependent but not time-dependent manner $\left(\mathrm{IC}_{50} 7.41 \mu \mathrm{M}\right.$ for $24 \mathrm{~h}, 7.35 \mu \mathrm{M}$ for $72 \mathrm{~h}$ ). Pyknosis was observed in 5b-treated U87 cells. Multiple intrinsic apoptotic pathways were induced by $5 \mathrm{~b}$ including the upregulation of caspase 9 , the release of cytochrome $\mathrm{c}$, an increase of the proapoptotic protein Bax, a decrease of the anti-apoptotic protein Bcl 2, and the activation of execution pathways by the upregulation of caspase 3. In addition to apoptosis, an autophagic mechanism was also involved in 5b-induced cytotoxicity to human GBM U87 cells by upregulating the expression of LC3-II and downregulating p62. Furthermore, $5 \mathrm{~b}$ also significantly attenuated the migration of U87 cells. Therefore, our results suggest that $5 \mathrm{~b}$ may be a promising molecule for the further development of a novel drug for the treatment of glioblastoma.
\end{abstract}

Received 2nd October 2018

Accepted 19th November 2018

DOI: 10.1039/c8ra08162j

rsc.li/rsc-advances activities; they are still the first-line drug for malarial treatment. ARTs have not only antimalarial property but also anticancer effects. ${ }^{4,5}$ It has been confirmed that dihydroartemisinin (DHA), the active metabolite of ARTs, showed cytotoxic activity on ten human glioma cell lines through the induction of autophagy. ${ }^{6}$ DHA also exerted an anti-tumor role through induced ROSmediated mitochondrion and ER stress apoptotic pathways as well as autophagic cell death in human GBM cells. ${ }^{7}$ Although ART and its derivatives are extremely effective in their antimalarial role, they are less potent as anticancer agents, especially as monotherapy drugs because of their mild activity and short elimination half-life. ${ }^{8}$ Therefore, to improve the clinical outcome of ARTs, future efforts should be focused on the combination of longer-acting drugs for maximum efficacy or the development of potent derivatives. ${ }^{9-11}$

Naturally occurring isothiocyanates (ITCs), which are generated by the enzymatic hydrolysis of glucosinolates, are abundant in cruciferous vegetables (Fig. 1). ${ }^{\mathbf{1 2 - 1 4}}$ It has been proven that some natural and synthetic ITCs have anticancer activities with multiple targets and mechanisms. ITCs can enhance the antitumor efficacy of other drugs, or act as covalent inhibitors. ${ }^{15}$ ITCs alone are able to suppress the growth of various cancer cell lines such as non-small-cell lung cancer cells, human malignant astrocytoma cells, and HCT 116 human colon cancer cells. ${ }^{16-20}$ They exert their effects mainly by increasing the production of reactive oxygen species (ROS), induction of apoptosis, induction of cell cycle arrest and so on. ${ }^{18-23}$ However, the exact mechanisms of ITCs against tumors are still not clear. Some research uncovered that aryl $\dagger$ Electronic supplementary information (ESI) available. See DOI: $10.1039 / \mathrm{c} 8 \mathrm{ra0} 08162 \mathrm{j}$

\$ These authors contributed equally to this work. 

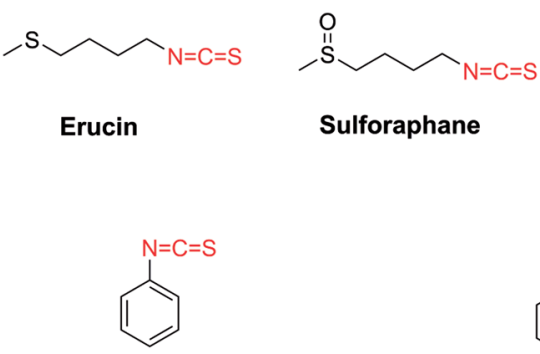

Phenyl isothiocyanate (PITC)<smiles>CS(=O)/C=C/CCN=C=S</smiles>

Sulforaphene $\sim \mathrm{N}=\mathrm{C}=\mathrm{S}$

Allyl isothiocyanate (AITC)

Benzyl isothiocyanate(BITC)

Fig. 1 The representatives of naturally occurring isothiocyanates.

isothiocyanates (e.g., benzyl isothiocyanate (BITC), phenyl isothiocyanate (PITC)) and allyl isothiocyanates (AITC) (Fig. 1) act as $\mathrm{H}_{2} \mathrm{~S}$ donor agents. ${ }^{24,25} \mathrm{H}_{2} \mathrm{~S}$ as the third most important gasotransmitter is involved in the development of cancer by shortening the cell cycle and inducing proliferation. ${ }^{26,27}$

Based on those studies, we hypothesized that artemisininbased isothiocyanates might be more efficacious compounds towards human GBM cells with multiple mechanisms. In this study, the synthesis, bio-evaluation and mechanism of artemisinin-based isothiocyanates against GBM in vitro have been carried out, and we found a novel DHA-ITC derivative $\mathbf{5 b}$ to have potent GBM cell toxicity.

\section{Results and discussion}

\section{Chemistry}

The synthetic strategy employed for the synthesis of the target compounds is depicted in Scheme 1. A series of novel hybrids were afforded by linking DHA at C-10 and an isothiocyanate group. The detailed synthetic route was described in Scheme 2 . The DHA derivatives $4 \mathbf{a}-\mathbf{c}$ were synthesized according to the literature. ${ }^{28,29}$ The reaction of DHA with the corresponding

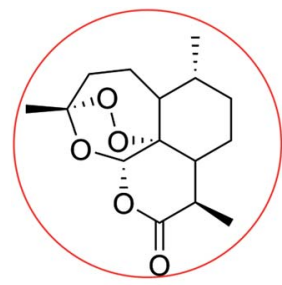

Artemisinin

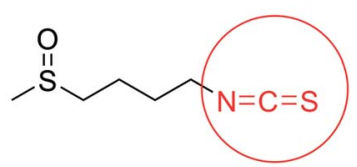

Sulforaphane

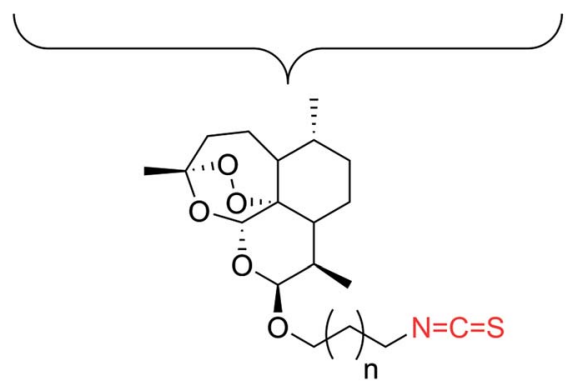

Scheme 1 The design strategy. bromo-substituted alkanol in $\mathrm{CH}_{2} \mathrm{Cl}_{2}$ by using boron trifluoride ethyl ether $\left(\mathrm{BF}_{3} \cdot \mathrm{Et}_{2} \mathrm{O}\right)$ as a catalyst afforded substituted ART enantiomers. 1a-c were obtained by silica gel column chromatography elution with petroleum ether/ethyl acetate $(97: 3)$ as the $\beta$ configuration (indicated the coupling constants between 9- $\mathrm{H}$ and $10-\mathrm{H}$ in ${ }^{1} \mathrm{H}$ NMR, $J_{9,10}=3-4 \mathrm{~Hz}$ ) ${ }^{30} \mathbf{1 a}-\mathbf{c}$ were then converted to 4a-c via an azidation and reduction reaction. Finally, the intermediates $\mathbf{4 a - c}$ bearing an amino group reacted with carbon disulfide $\left(\mathrm{CS}_{2}\right)$ in dried $\mathrm{THF}^{31}$ to afford the target compounds $\mathbf{5 a}-\mathbf{c}$. All the synthesized compounds were purified by silica gel column chromatography.

The structures of compounds $5 \mathbf{a}-\mathbf{c}$ were elucidated on the basis of ${ }^{1} \mathrm{H}$ NMR, ${ }^{13} \mathrm{C}$ NMR and HR-ESI-MS spectra. In a typical example, the HR-ESI-MS of compound $\mathbf{5 b}$ displayed a peak at $m /$ $z$ 384.1802, corresponding to the quasimolecular ions $[\mathrm{M}+\mathrm{H}]^{+}$, confirming the molecular formula of compound $5 \mathbf{b}$ as $\mathrm{C}_{19} \mathrm{H}_{29} \mathrm{NO}_{5} \mathrm{~S}$. In the ${ }^{1} \mathrm{H}-\mathrm{NMR}$ spectrum of $5 \mathbf{b}$, the signals of one singlet at $\delta 1.42$ and two doublets at $\delta 0.89$ and 0.94 could be attributed to Me-14, Me-16 and Me-15, respectively. The doublet peak appearing at $\delta 4.78(\mathrm{~d}, J=3.2 \mathrm{~Hz})$ indicated $\mathrm{H}-10$ in the $\alpha$ configuration. ${ }^{30}$ In the ${ }^{13} \mathrm{C}-\mathrm{NMR}$ spectrum, there were 19 peaks appearing in the range from $\delta 12$ to $130 \mathrm{ppm}$. Among them, a weak peak appearing at $\delta 129.5$ could be ascribed to the carbon of the isothiocyanate $(-\mathrm{N}=\mathrm{C}=\mathrm{S})$. The other NMR characterizations have been assigned through the comparison of relative data in literature..$^{32,33}$

\section{Biological evaluation}

Artemisinin-based isothiocyanate derivatives induced cytotoxicity in glioblastoma U87 cells. The cytotoxicity of artemisinin-based isothiocyanate derivatives on human glioblastoma U87 cells was firstly tested by MTT assay. U87 cells were exposed to various concentrations of compounds for $24 \mathrm{~h}$, and all compounds could induce cell death by MTT assay (Table 1). Cells shrunk and fragmented when exposed to compounds under the phase-contrast microscope (Fig. 2). Among all the compounds, 5b showed the most cytotoxic activity with an $\mathrm{IC}_{50}$ value of $7.41 \mu \mathrm{M}$ and was thus selected for further experiments. As shown in Fig. 3, 5b reduced the viability of GBM cells in a concentration-dependent manner. To evaluate the effects of 5b on the proliferative cancer cell line, U87 glioblastoma cells were exposed to various concentrations of $\mathbf{5 b}$ for different durations. 5b significantly suppressed the survival of U87 cells 


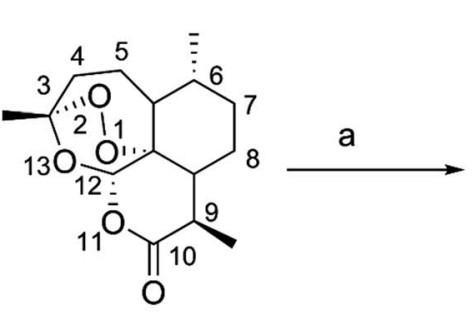

Artemisinin (ART)

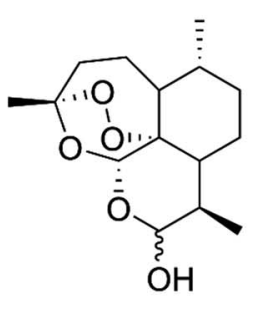

Dihydroartemisinin (DHA)

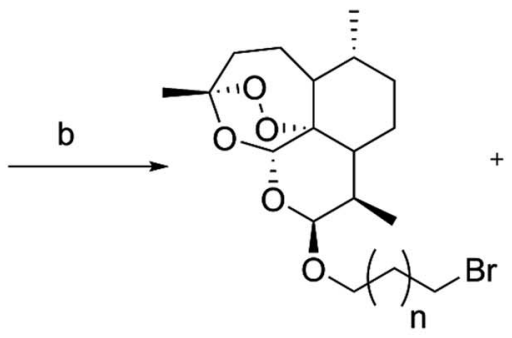

$1 \mathrm{a}, \mathrm{n}=\mathbf{0}$ $1 \mathrm{~b}, \mathrm{n}=1$ $1 c, n=4$

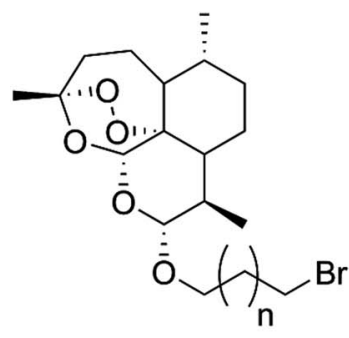

2
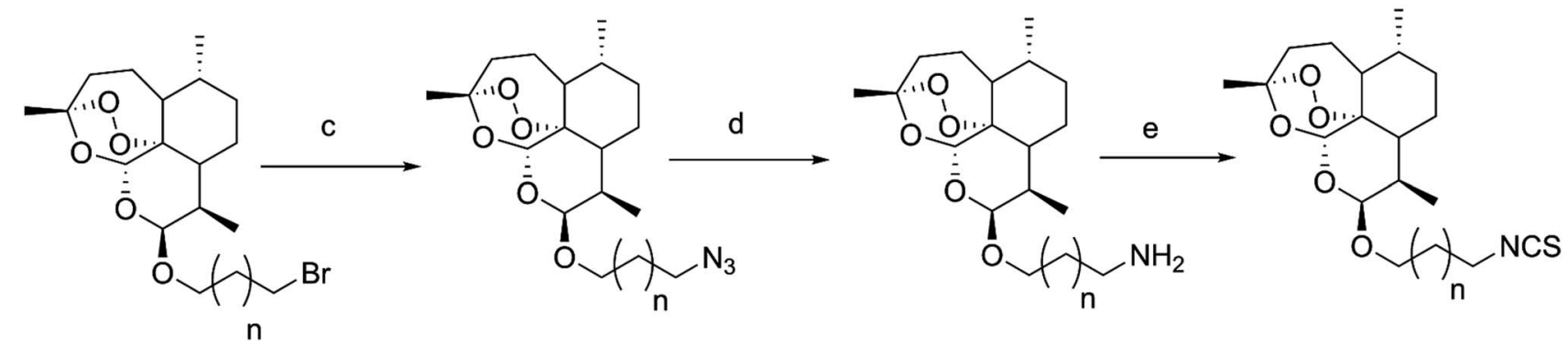

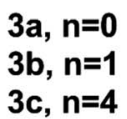
$4 a, n=0$
$4 b, n=1$
$4 c, n=4$

$5 a, n=0$
$5 b, n=1$
$5 c, n=4$

Scheme 2 The synthetic route of artemisinin-isothiocyanate derivatives $5 \mathrm{a}-\mathrm{c}$. Reagents and conditions: ${ }^{\mathrm{a}} \mathrm{NaBH} 4 / \mathrm{MeOH}, 0{ }^{\circ} \mathrm{C}, 2 \mathrm{~h}, 94 \%$; ${ }^{b} \mathrm{BF}_{3} \cdot \mathrm{Et}_{2} \mathrm{O} / \mathrm{CH}_{2} \mathrm{Cl}_{2}$, bromo-substituted alkanol; ${ }^{\mathrm{C}} \mathrm{NaN}_{3} / \mathrm{Nal} / \mathrm{DMF}, 60{ }^{\circ} \mathrm{C}, 4 \mathrm{~h}, 85-98 \%{ }^{d}(1)(\mathrm{Ph}){ }_{3} \mathrm{P} / \mathrm{THF}, 60{ }^{\circ} \mathrm{C}, 2 \mathrm{~h} ;(2) \mathrm{H} \mathrm{O} \mathrm{O}, 70{ }^{\circ} \mathrm{C}, 2 \mathrm{~h}, 65-91 \%$; ${ }^{e} \mathrm{CS}_{2} / \mathrm{THF} / \mathrm{Et}_{3} \mathrm{~N}, 0{ }^{\circ} \mathrm{C}-$ r.t, $30 \mathrm{~min}$, then $\mathrm{AcCl}, 0{ }^{\circ} \mathrm{C}$-r.t, $30 \mathrm{~min}, 49-76 \%$.

and the inhibitory efficiency was stronger than that of DHA (see Table 1 and Fig. 3).

Artemisinin-based isothiocyanate derivative $5 \mathbf{b}$ inhibits cell migration. Cell migration is a landmark of cancer invasion and metastasis, immune responses, angiogenesis, wound repair, and embryonic morphogenesis. ${ }^{34}$ Wound-healing assay is

Table $1 \quad I C_{50}$ values $(\mu M)$ against human U87 cells

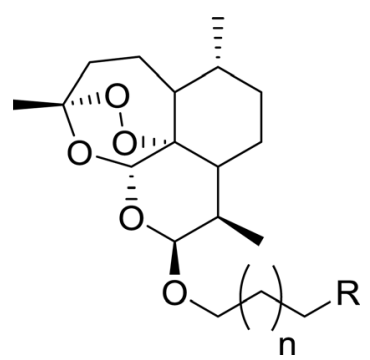

\begin{tabular}{lllc}
\hline Compounds & $n$ & $\mathrm{R}$ & $\mathrm{IC}_{50}{ }^{a}$ \\
\hline $\mathbf{4 b}$ & 1 & $-\mathrm{NH}_{2}$ & $>120$ \\
$\mathbf{4 c}$ & 4 & $-\mathrm{NH}_{2}$ & $118.26 \pm 15.12$ \\
$\mathbf{5 a}$ & 0 & $-\mathrm{N}=\mathrm{C}=\mathrm{S}$ & $27.32 \pm 3.65$ \\
$\mathbf{5 b}$ & 1 & $-\mathrm{N}=\mathrm{C}=\mathrm{S}$ & $7.41 \pm 1.56$ \\
$\mathbf{5 c}$ & 4 & $-\mathrm{N}=\mathrm{C}=\mathrm{S}$ & $20.29 \pm 4.17$ \\
Dihydroartemisinin (DHA) & & & $118.95 \pm 12.39$
\end{tabular}

${ }^{a}$ After $24 \mathrm{~h}$ incubation. a well-established test of cancer cell migration. To investigate the effects of $\mathbf{5 b}$ on wound-healing phenomena, cells were exposed to $4 \mu \mathrm{M}$ (around half of the $\mathrm{IC}_{50}$ ) of $5 \mathrm{~b}$ for $0-72 \mathrm{~h} \cdot .^{35}$ The migration of U87 cells was reduced significantly by $5 \mathbf{b}$ (Fig. 4).

Artemisinin-based isothiocyanate derivative $5 \mathrm{~b}$ induces apoptosis in $\mathbf{U} 87$ cells. To determine the cell death pathway, the U87 cells were treated with two doses ( 8 and $16 \mu \mathrm{M})$ of $\mathbf{5 b}$, which were selected to determine the apoptotic effects of $\mathbf{5 b}$ in a concentration-dependent manner. After $16 \mathrm{~h}$ of incubation, apoptotic markers of treated cells were analyzed with fluorescein isothiocyanate (FITC)-conjugated annexin V and PI. Annexin V detects phosphatidylserine (PS) on the cell membrane during apoptosis. Propidium iodide (PI) stains the DNA of apoptotic and necrotic cells. As shown in Fig. 5A, 5b induced a higher proportion of early apoptotic and necrotic cells. The nuclear morphological changes were examined by DAPI staining. Pyknosis and nuclear shrinkage were observed in 5b-treated cells (Fig. 5B).

To support the fact that apoptosis was involved in the cytotoxic effects of 5b on GBM cells, we further investigated the caspase family apoptotic proteins and the Bcl2 family apoptotic proteins. As there are three classical apoptotic pathways, we investigated intrinsic and execution pathways. As shown in Fig. 6, the caspase family apoptotic proteins were induced in U87 cells treated with various concentrations of $5 \mathbf{b}(4-16 \mu \mathrm{M})$ and DHA $(120 \mu \mathrm{M})$ for $16 \mathrm{~h}$. Caspase 9 and cytochrome $c$ were induced in U87 cells treated with $\mathbf{5 b}$. It was assumed that 

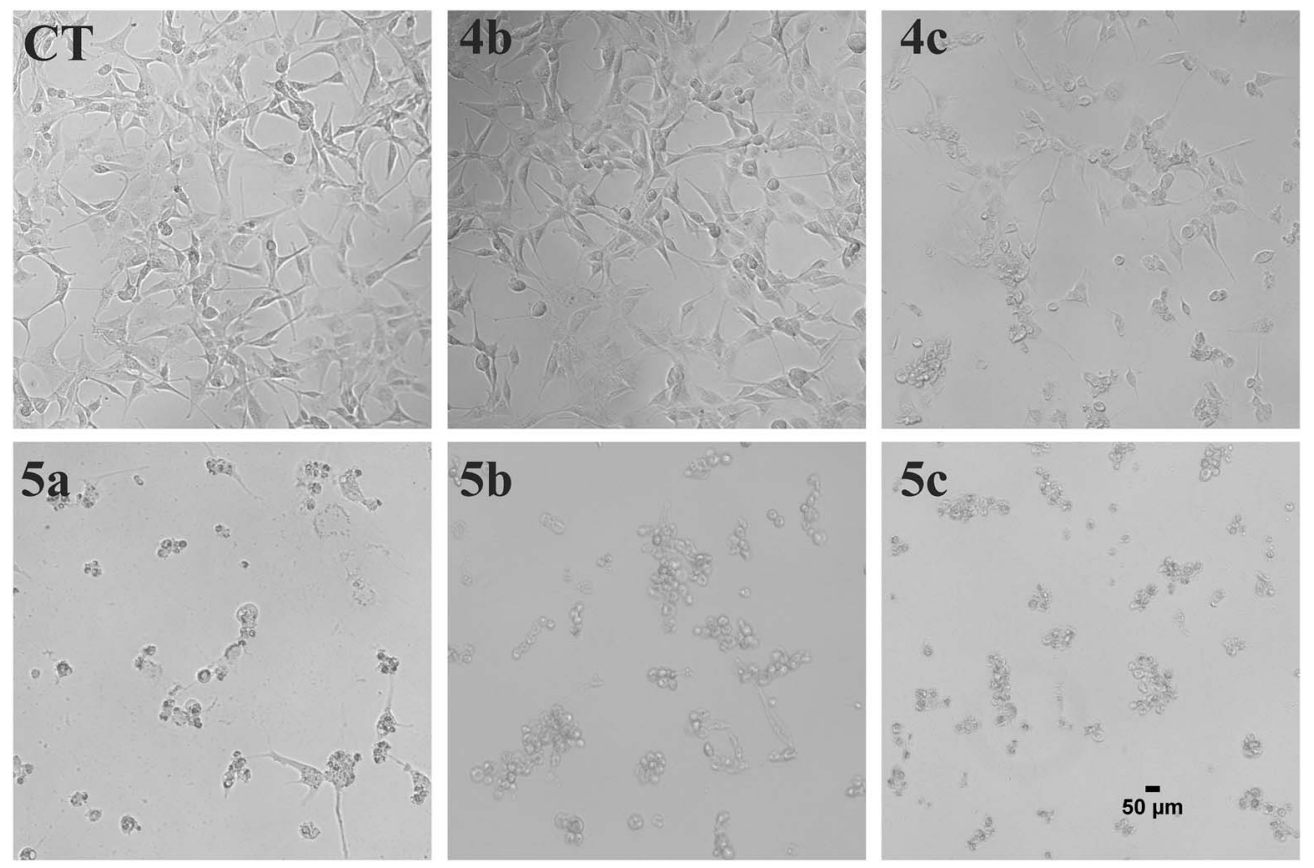

Fig. 2 Morphological examination of U87 cells treated with artemisinin-isothiocyanates (5a-c) and the key intermediates (4b, 4c). The cells were treated with $30 \mu \mathrm{M}$ of the compounds for $24 \mathrm{~h}$ and the morphological changes were examined with phase contrast microscope. Scale bar $=50$ $\mu \mathrm{m}$.

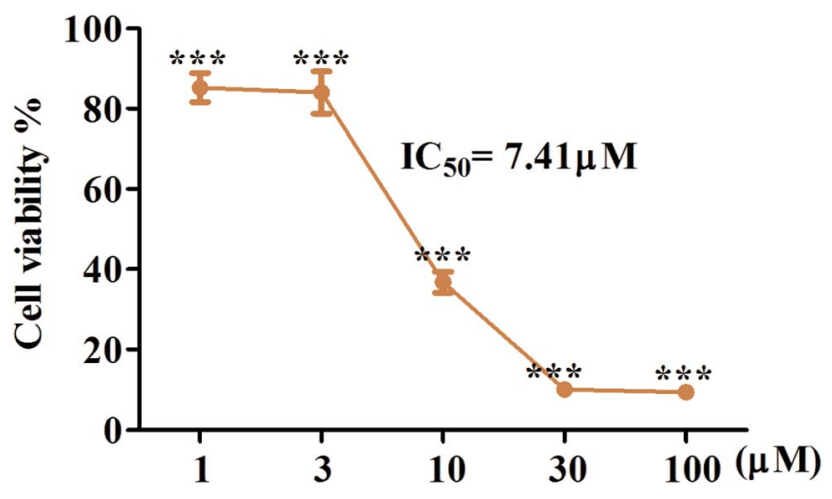

Fig. $35 \mathrm{~b}$ possesses the cytotoxic activity on human GBM cell lines, U87. The cells were treated with indicated concentrations of $5 \mathrm{~b}$ for $24 \mathrm{~h}$. Cell viability was tested via MTT assay and $I C_{50}$ value was calculated. $5 \mathrm{~b}$ reduced the cell viability of $U 87$ cells in a concentration dependent manner. All data were represented as mean \pm SD from three independent experiments; ${ }^{* * * P}<0.001$ versus control.

release of cytochrome $c$ activated the caspase-dependent mitochondrial pathway. Cytochrome $c$ binds and activates Apaf1 as well as procaspase-9, forming an "apoptosome". The clustering of procaspase-9 leads to caspase-9 activation. ${ }^{36,37}$ The antiapoptotic protein Bcl-2 was downregulated and pro-apoptotic protein BAX was upregulated in 5b-treated cells. The Bcl-2 family of proteins governs mitochondrial membrane permeability via the regulation of cytochrome $c$ released from the mitochondria. $^{36}$ Caspase 3 is considered to be the most important of the executioner caspases in apoptotic cell death. Cleaved (active) caspase 3 was increased in $\mathbf{5 b}$-treated cells (Fig. 6).
Artemisinin-based isothiocyanate derivative $5 \mathrm{~b}$ induces autophagy in U87 cells. Autophagy assures cellular homeostasis and is gaining increasing importance in cancer treatment, where it impacts carcinogenesis as well as the propagation of the malignant phenotype and the development of resistance. ${ }^{38}$ To observe whether autophagy was also involved in $\mathbf{5 b}$-induced cytotoxicity, autophagic markers, such as LC3-II, microtubuleassociated proteins 1A/1B light chain 3B, and p62/SQSTM1, were investigated in U87 cells treated with $\mathbf{5 b}$ for $16 \mathrm{~h}$. LC3-II expression increased in the $\mathbf{5 b}$-treated group compared to the control groups. Moreover, the decrease of p62 was observed in the 5b-treated group (Fig. 7).

\section{Conclusion}

In conclusion, novel ART derivatives containing an ITC group have been synthesized. All the compounds showed more potent activity than that of the parent DHA towards glioblastoma multiforme U87 in vitro. The data in the present study demonstrated that $\mathbf{5 b}$ significantly induced cytotoxicity $\left(\mathrm{IC}_{50} 7.41 \mu \mathrm{M}\right)$ towards human GBM cells through inducing both apoptotic and autophagic cell death and also inhibited the migration of human GBM cells. It was a stronger inducer in GBM cells compared to DHA (about twenty times stronger). Therefore, it suggested that $\mathbf{5 b}$ may be a potential multifunctional small molecule for developing new drugs for the treatment of GBM.

\section{Experimental}

\section{Chemistry}

Melting points were measured on an XT-4 apparatus (TaikeCorp., Beijing, China) and were uncorrected. ${ }^{1} \mathrm{H}$ and ${ }^{13} \mathrm{C}$ NMR 
A.
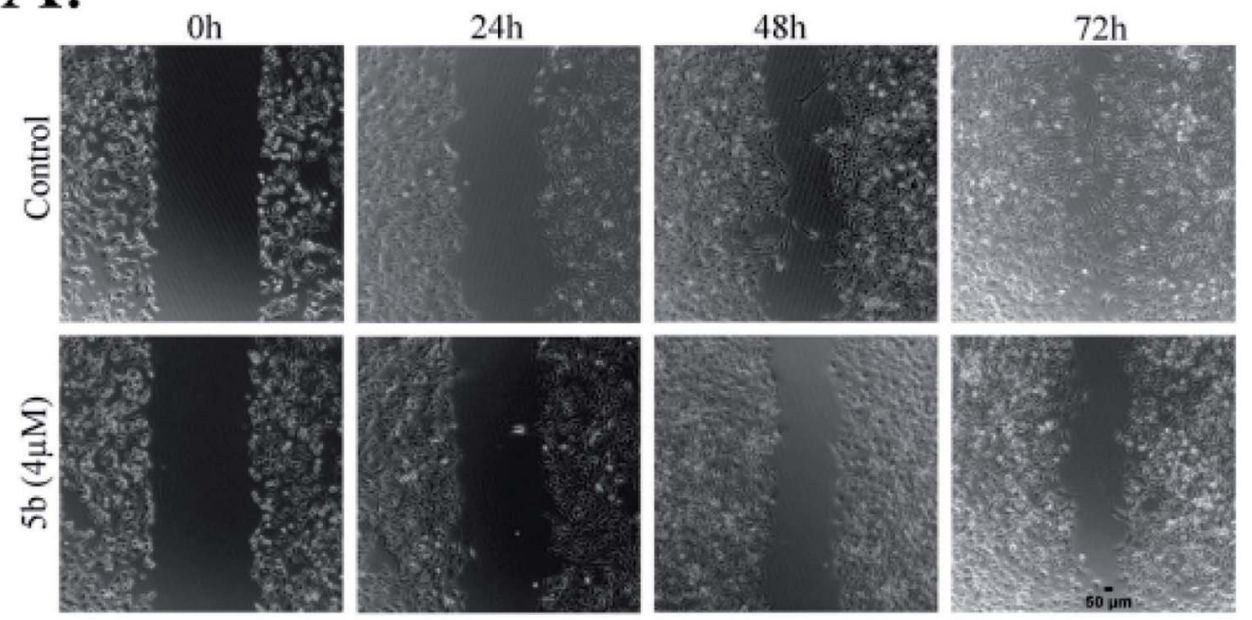
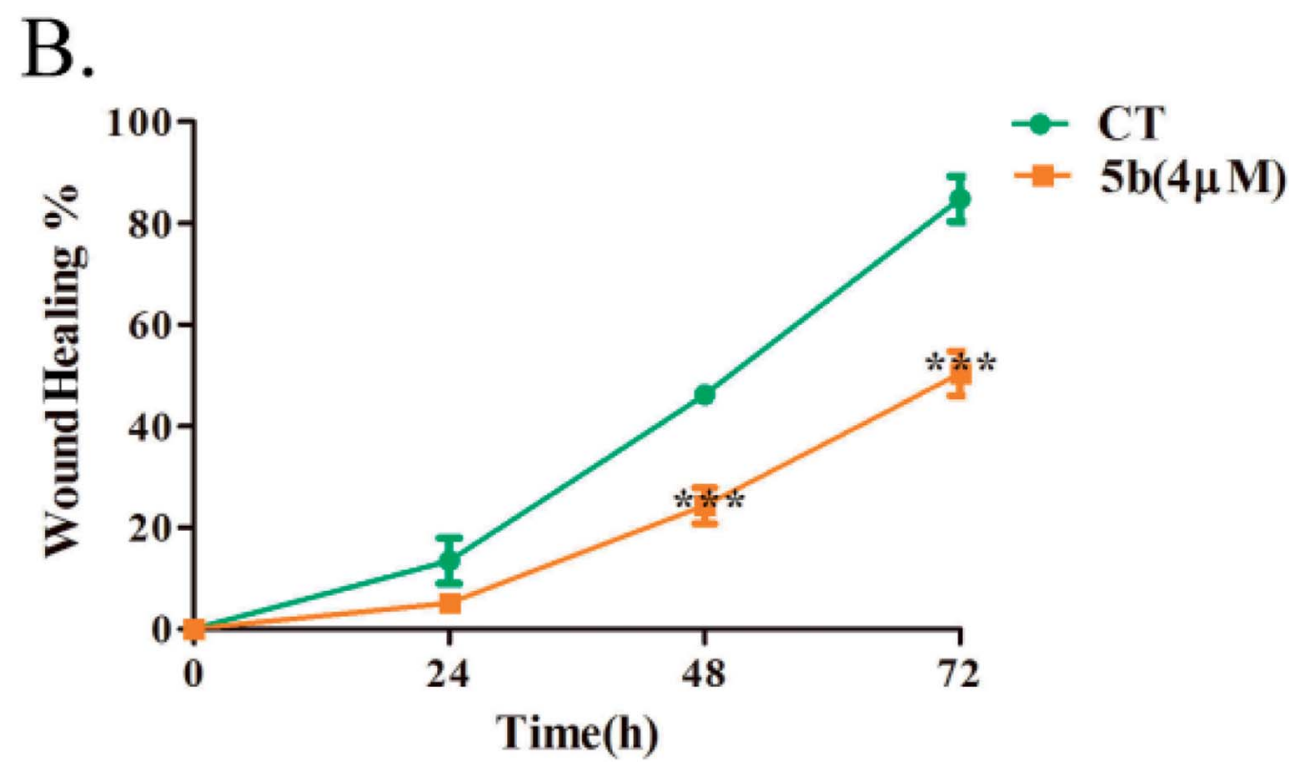

Fig. $45 \mathrm{~b}$ inhibits the migration of human glioblastoma cells, U87. Data were expressed as means $\pm \mathrm{SD}$. $* * * P<0.001$ versus control. All experiments were performed in triplicates.

spectra were recorded on Bruker $400 \mathrm{MHz}$, and the data were recorded using $\mathrm{CDCl}_{3}$ as the solvent. Chemical shifts $(\delta)$ are reported in ppm downfield from an internal TMS standard. HRESI-MS spectra were determined on an AB SciexTripleTOF $5600^{+}$ apparatus. Flash column chromatography on silica gel (200-300 mesh) was used for the routine purification of the reaction products. Analytical TLC was performed on silica gel $60 \mathrm{~F}_{254}$ plates (Merck KGaA, Darmstadt, Germany). All solvents and chemical reagents were obtained from commercial sources and used without further purifications.

\section{General procedure for the synthesis of compounds 1a-c}

The DHA derivatives 1a-c were synthesized via the reaction of DHA with the corresponding bromo-substituted alkanol in $\mathrm{CH}_{2} \mathrm{Cl}_{2}$ using boron trifluoride ethyl ether $\left(\mathrm{BF}_{3} \cdot \mathrm{Et}_{2} \mathrm{O}\right)^{28,29}$ and isolation in the $\beta$ configuration by silica gel column chromatography elution with petroleum ether/ethyl acetate (97:3) (indicated are the coupling constants between 9- $\mathrm{H}$ and $10-\mathrm{H}$ in ${ }^{1} \mathrm{H}$ NMR, $\left.J_{9,10}=3-4 \mathrm{~Hz}\right){ }^{30}$

The solution of DHA (3.0 mmol) and 3-bromo-1-propanol, or 2-bromo-1-ethanol, or 6-bromo-hexanol (4.6 mmol) in $\mathrm{CH}_{2} \mathrm{Cl}_{2}$ $(20 \mathrm{~mL})$ below $0{ }^{\circ} \mathrm{C}$ was added to $\mathrm{BF}_{3} \cdot \mathrm{Et}_{2} \mathrm{O}(0.63 \mathrm{~mL}, 5.0 \mathrm{mmol})$. The mixture was stirred for about $50 \mathrm{~min}$ at the same temperature under nitrogen protection and monitored by TLC. At the end of the reaction, the organic layer was collected and washed with saturated $\mathrm{NaHCO}_{3}$ solution $(1 \times 20 \mathrm{~mL})$, water $(1 \times 20 \mathrm{~mL})$ and brine $(1 \times 20 \mathrm{~mL})$, dried over anhydrous $\mathrm{Na}_{2} \mathrm{SO}_{4}$ and then concentrated in vacuo to give the crude product, which was purified by silica gel column chromatography (ether/ethyl acetate, $97: 3, \mathrm{v} / \mathrm{v}$ ) to afford compounds $\mathbf{1 a}-\mathbf{c}$.

1-Bromo-2-(10ß-dihydroartemisinoxy)ethane (1a). Colorless solid; yield: $36 \%$; mp $73-74{ }^{\circ} \mathrm{C} ;{ }^{1} \mathrm{H}$ NMR (refer to literature 28 ); ${ }^{13} \mathrm{C}$ NMR $\left(100 \mathrm{MHz}, \mathrm{CDCl}_{3}\right) \delta 104.3(\mathrm{C}-3), 102.2(\mathrm{C}-10), 88.3(\mathrm{C}-12)$, 

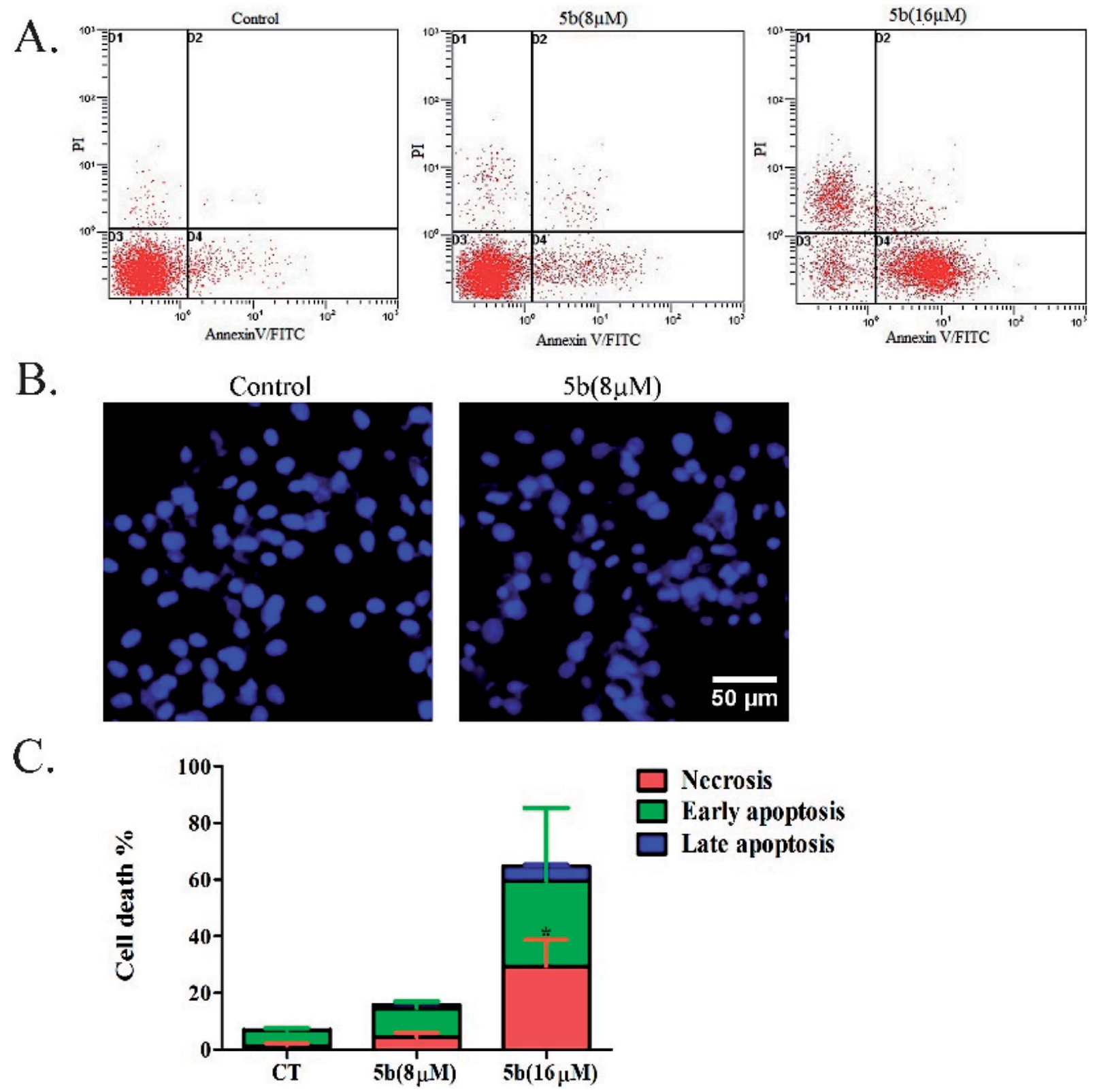

Fig. 5 Apoptotic analysis of 5b on U87 glioblastoma cells. (A) U87 cells were treated with DMSO or 8 and $16 \mu M$ concentrations of $5 \mathrm{~b}$ for $16 \mathrm{~h}$, and apoptotic rates were analyzed by flow cytometry after annexin V/PI staining. (B) U87 cells were treated with DMSO or $8 \mu M$ of $5 \mathrm{~b}$ for $16 \mathrm{~h}$ and the nuclear morphological changes were observed using DAPI staining and fluorescence microscope. (C) Data are expressed as mean \pm SD of three independent experiments presented in (A). $* P<0.05$ versus control.

81.3(C-12a), 68.4(- $\left.\mathrm{OCH}_{2}-\right)$, 52.8(C-5a), 44.5(C-8a), 37.6(C-6), 36.6(C-4), 34.9(C-7), 31.6(C-9), 31.1 $\left(\mathrm{BrCH}_{2}-\right), \quad 26.4(\mathrm{C}-14)$, 24.8(C-5), 24.6(C-8), 20.6(C-15), 13.2(C-16).

1-Bromo-3-(10ß-dihydroartemisinoxy)propane (1b). Colorless solid; yield: $39 \%$; mp: $69-71{ }^{\circ} \mathrm{C} ;{ }^{1} \mathrm{H}$ NMR (refer to literature 29);; ${ }^{13} \mathrm{C}$ NMR (100 MHz, $\left.\mathrm{CDCl}_{3}\right) \delta 104.3(\mathrm{C}-3), 102.3(\mathrm{C}-10)$, 88.1(C-12), 81.2(C-12a), 65.8(- $\left.\mathrm{OCH}_{2}-\right)$, 52.7(C-5a), 44.5(C-8a), 37.6(C-6), 36.6(C-4), 34.8(C-7), 32.7(C-9), 31.1 $\left(\mathrm{BrCH}_{2}^{-}\right)$, $30.8\left(\mathrm{BrCH}_{2} \mathrm{CH}_{2}-\right)$, 26.4(C-14), 24.8(C-5), 24.7(C-8), 20.5(C15), 13.2(C-16).
1-Bromo-6-(10ß-dihydroartemisinoxy)hexane (1c). Colorless oil; yield: $40 \% ;{ }^{1} \mathrm{H}$ NMR (400 MHz, $\left.\mathrm{CDCl}_{3}\right) \delta 5.35$ (s, $1 \mathrm{H}, \mathrm{H}-12$ ), 4.76 (d, $J=3.0 \mathrm{~Hz}, 1 \mathrm{H}, \mathrm{H}-10), 3.98-3.85$ (m, $\left.1 \mathrm{H},-\mathrm{OCH}_{2}-\right)$, 3.46$3.37\left(\mathrm{~m}, 2 \mathrm{H},-\mathrm{CH}_{2} \mathrm{Br}\right), 3.34\left(\mathrm{t}, J=6.7 \mathrm{~Hz}, 1 \mathrm{H},-\mathrm{OCH}_{2}-\right), 2.68-2.50$ (m, 1H, H-9), 2.34 (td, $J=14.1,3.7 \mathrm{~Hz}, 1 \mathrm{H}, \mathrm{H}-4), 2.01$ (d, $J=$ $14.3 \mathrm{~Hz}, 1 \mathrm{H}, \mathrm{H}-4), 1.66-1.56$ (m, 2H), 1.53-1.42 (m, 2H), 1.40 (s, $\left.3 \mathrm{H}, \mathrm{CH}_{3}-14\right), 1.36-1.26(\mathrm{~m}, 1 \mathrm{H}), 1.25-1.18(\mathrm{~m}, 1 \mathrm{H}), 0.92(\mathrm{~d}, J=$ $\left.6.2 \mathrm{~Hz}, 3 \mathrm{H}, \mathrm{CH}_{3}-15\right), 0.87$ (d, $\left.J=7.2 \mathrm{~Hz}, 3 \mathrm{H}, \mathrm{CH}_{3}-16\right), 0.87(\mathrm{~m}$, $1 \mathrm{H}, \mathrm{H}-7) ;{ }^{13} \mathrm{C}$ NMR (100 MHz, $\left.\mathrm{CDCl}_{3}\right) \delta 104.3(\mathrm{C}-3), 102.2(\mathrm{C}-10)$, 88.1(C-12), 81.2(C-12a), 68.4(-OCH $\left.{ }_{2}-\right), 52.8(\mathrm{C}-5 \mathrm{a}), 44.7(\mathrm{C}-8 \mathrm{a})$, 37.7(C-6), 36.7(C-4), 34.9(C-7), 34.0, 32.9(C-9), 31.1, 29.7, 28.1, 26.4(C-14), 25.7, 24.9(C-5), 24.7(C-8), 20.6(C-15), 13.1(C-16). 
Cytochrome C

BCL2

BAX

Pro caspase 3

Cleaved caspase 3

Pro caspase 9

Cleaved caspase 9

$\beta$-Actin

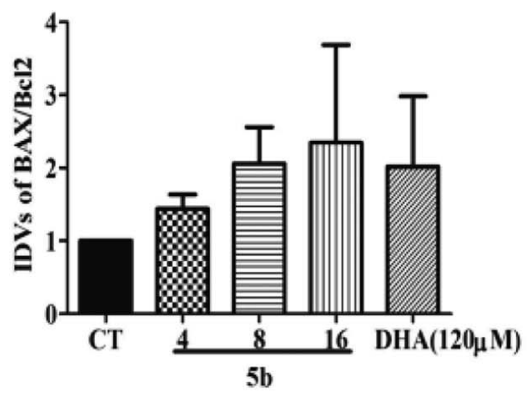

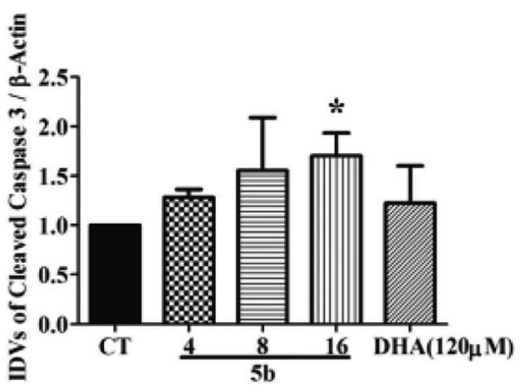
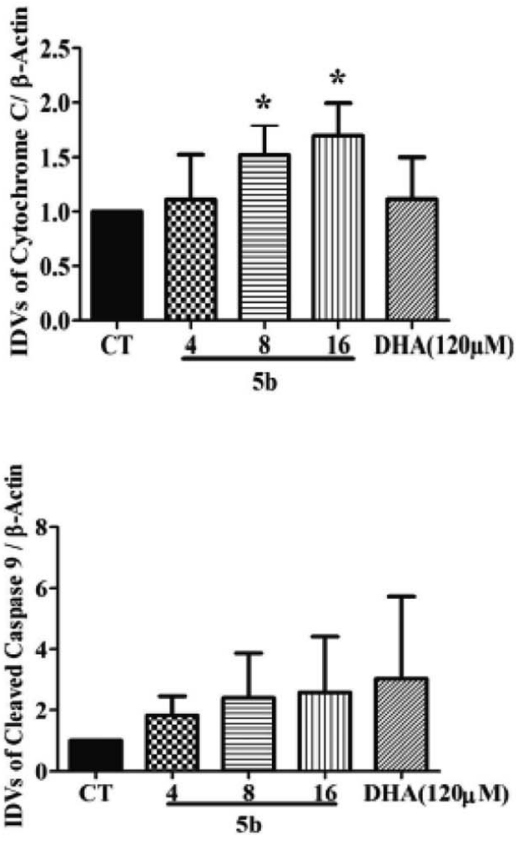

Fig. $65 \mathrm{~b}$ induces apoptosis by regulating caspase family proteins and Bcl2 family proteins in human GBM cells. Cells were treated with the indicated concentrations of $5 \mathrm{~b}$ and DHA for $16 \mathrm{~h}$. The proteins were collected for western blot assay and $\beta$-actin was used as protein loading control. The result was obtained by three different independent experiments.
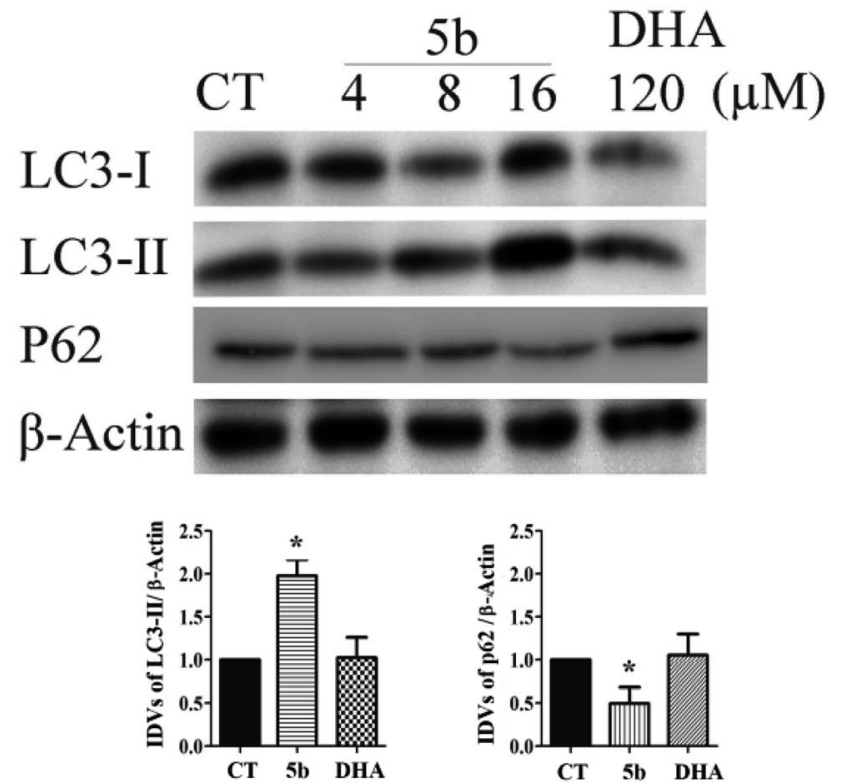

Fig. 7 bb induces autophagy in human GBM cells. Cells were treated with the indicated concentrations of $5 \mathrm{~b}$ and $\mathrm{DHA}$ for $16 \mathrm{~h}$. The proteins were collected for western blot assay with LC3B, p62 and $\beta$-actin antibodies. The result was obtained by three different independent experiments.

\section{General procedure for the synthesis of compounds $3 a-c$}

The intermediate $\mathbf{3 a - c}$ was synthesized from 1a-c according to the procedure previously reported..$^{28,29}$ To the solution of $\mathbf{1 a - c}$ $(0.89 \mathrm{mmol})$ and $\mathrm{NaI}(10.0 \mathrm{mg})$ in DMF $(5.0 \mathrm{~mL}), \mathrm{NaN}_{3}(2.7$ mmol) was added. The reaction mixture was heated to $60^{\circ} \mathrm{C}$ for $4 \mathrm{~h}$. After the disappearance of the starting material, the solution was poured into ice water $(20 \mathrm{~mL})$, stirred for $1 \mathrm{~h}$, and then extracted with $\mathrm{CH}_{2} \mathrm{Cl}_{2}(3 \times 20 \mathrm{~mL})$, dried over anhydrous $\mathrm{Na}_{2} \mathrm{SO}_{4}$ and concentrated to give a light yellow oil. The crude product was further purified by silica gel column chromatography (petroleum ether/ethyl acetate, $9: 1$, v/v) to provide $3 \mathbf{a}-\mathbf{c}$.

Table 2 Information of antibodies for western blot

\begin{tabular}{llll}
\hline Antibody name & Manufacturer & Catalog & Dilutions \\
\hline Primary antibody & & & \\
Bax & ABclonal & A2211 & $1: 1000$ \\
BCL2 & ABclonal & A0208 & $1: 1000$ \\
Caspase 3 & Cell signaling technology & 9665 & $1: 1000$ \\
Caspase 9 & Cell signaling technology & 9508 & $1: 1000$ \\
Cytochrome C & Cell signaling technology & 11940 & $1: 1000$ \\
LC3B & Cell signaling technology & 3868 & $1: 1000$ \\
P62 & MBL & PM045 & $1: 1000$ \\
$\beta$-Actin & Thermo Fisher & MA5-11869 & $1: 2500$
\end{tabular}

\section{Secondary antibody}

$\begin{array}{lll}\text { Anti-rabbit } & \text { Beyotime } & \text { A0208 } \\ \text { Anti-mouse } & \text { Beyotime }\end{array}$


2-(10ß-Dihydroartemisinoxy)ethyl azide (3a). Colorless solid; yield: $85 \%$; mp: $86-87{ }^{\circ} \mathrm{C} ;{ }^{1} \mathrm{H}$ NMR (refer to literature 28 ); ${ }^{13} \mathrm{C}$ NMR (100 MHz, $\mathrm{CDCl}_{3}$ ) $\delta 104.34(\mathrm{C}-3), 102.59(\mathrm{C}-10), 88.14(\mathrm{C}-12)$, 81.22(C-12a), 67.47(-- $\left.\mathrm{OCH}_{2}-\right), \quad 52.70(\mathrm{C}-5 \mathrm{a}), \quad 51.33\left(-\mathrm{CH}_{2} \mathrm{~N}_{3}\right)$, 44.54(C-8a), 37.57(C-6), 36.56(C-4), 34.75(C-7), 30.93(C-9), 26.32(C-14), 24.84(C-5), 24.56(C-8), 20.53(C-15), 13.10(C-16).

3-(10ß-Dihydroartemisinoxy)propyl azide (3b). Colorless solid; yield: 94\%; mp: 80-82 ${ }^{\circ} \mathrm{C}$; ${ }^{1} \mathrm{H}$ NMR (400 $\mathrm{MHz}, \mathrm{CDCl}_{3}$ ) $\delta 5.35(\mathrm{~s}, 1 \mathrm{H}, \mathrm{H}-12), 4.76(\mathrm{~d}, J=3.1 \mathrm{~Hz}, 1 \mathrm{H}, \mathrm{H}-10), 3.97-3.84(\mathrm{~m}$, $\left.1 \mathrm{H},-\mathrm{OCH}_{2}-\right)$, 3.49-3.38 (m, $\left.1 \mathrm{H},-\mathrm{OCH}_{2}-\right), 3.34(\mathrm{t}, J=6.7 \mathrm{~Hz}, 2 \mathrm{H}$, $-\mathrm{CH}_{2} \mathrm{~N}_{3}$ ), 2.68-2.53 (m, 1H, H-9), $2.34(\mathrm{td}, J=14.0,3.8 \mathrm{~Hz}, 1 \mathrm{H}$, $\mathrm{H}-4), 2.00$ (m, 1H, H-4), 1.83 (m, 3H), 1.77-1.68 (m, 2H), 1.661.56 (m, 2H), 1.54-1.42 (m, 2H), 1.40 (s, 3H, $\left.\mathrm{CH}_{3}-14\right), 1.35-1.24$ $(\mathrm{m}, 1 \mathrm{H}), 1.24-1.12(\mathrm{~m}, 1 \mathrm{H}), 0.92\left(\mathrm{~d}, J=6.2 \mathrm{~Hz}, 3 \mathrm{H}, \mathrm{CH}_{3}-15\right), 0.87$ (d, $\left.J=7.3 \mathrm{~Hz}, 3 \mathrm{H}, \mathrm{CH}_{3}-16\right), 0.87(\mathrm{~m}, 1 \mathrm{H}, \mathrm{H}-7) ;{ }^{13} \mathrm{C}$ NMR $(100$ $\left.\mathrm{MHz}, \mathrm{CDCl}_{3}\right) \delta 104.3(\mathrm{C}-3), 102.3(\mathrm{C}-10), 88.1(\mathrm{C}-12), 81.2(\mathrm{C}-12 \mathrm{a})$, 65.2(- $\left.\mathrm{OCH}_{2}-\right)$, 52.7(C-5a), 48.8 $\left(-\mathrm{CH}_{2} \mathrm{~N}_{3}\right), 44.5(\mathrm{C}-8 \mathrm{a}), 37.6(\mathrm{C}-6)$, 36.6(C-4), 34.8(C-7), 31.1(C-9), 29.3( $\left.\mathrm{N}_{3} \underline{\mathrm{CH}_{2}} \mathrm{CH}_{2}-\right)$, 26.8(C-

14), 24.8(C-5), 24.7(C-8), 20.5(C-15), 13.2(C-16).

6-(10ß-Dihydroartemisinoxy)hexyl azide (3c). Colorless oil; yield: $98 \% ;{ }^{1} \mathrm{H}$ NMR (400 MHz, $\left.\mathrm{CDCl}_{3}\right) \delta 5.36$ (s, 1H, H-12), 4.75 (d, $J=3.0 \mathrm{~Hz}, 1 \mathrm{H}, \mathrm{H}-10), 3.89-3.74\left(\mathrm{~m}, 1 \mathrm{H},-\mathrm{OCH}_{2}-\right.$ ), 3.40-3.30 $\left(\mathrm{m}, 1 \mathrm{H},-\mathrm{OCH}_{2}-\right), 3.23\left(\mathrm{t}, J=6.5 \mathrm{~Hz}, 2 \mathrm{H},-\mathrm{CH}_{2} \mathrm{~N}_{3}\right), 2.59(\mathrm{~m}$, $1 \mathrm{H}, \mathrm{H}-9), 2.34$ (t, J=13.9 Hz, 1H, H-4), $2.00(\mathrm{~m}, 1 \mathrm{H}, \mathrm{H}-4), 1.80(\mathrm{~m}$, $3 \mathrm{H}), 1.51$ (m, 5H), 1.41 (s, 3H, $\left.\mathrm{CH}_{3}-14\right), 1.38$ (m, 7H), 1.26-1.12 $(\mathrm{m}, 3 \mathrm{H}), 0.93\left(\mathrm{~d}, J=6.0 \mathrm{~Hz}, 3 \mathrm{H}, \mathrm{CH}_{3}-15\right), 0.87$ (d, $J=6.6 \mathrm{~Hz}, 3 \mathrm{H}$, $\left.\mathrm{CH}_{3}-16\right)$, 0.85-0.78 (m, 1H, H-7); ${ }^{13} \mathrm{C} \mathrm{NMR} \mathrm{(100} \mathrm{MHz,} \mathrm{CDCl}_{3}$ ) $\delta$ 104.3(C-3), 102.2(C-10), 88.1(C-12), 81.3(C-12a), 68.4(- $\left.\mathrm{OCH}_{2}-\right)$, 52.8(C-5a), 51.6(- $\left.\mathrm{CH}_{2} \mathrm{~N}_{3}\right), \quad 44.7(\mathrm{C}-8 \mathrm{a}), \quad 37.7(\mathrm{C}-6), \quad 36.7(\mathrm{C}-4)$, 34.9(C-7), 31.1(C-9), 29.7, 29.0, 26.7, 26.4(C-14), 26.1, 24.9(C-5), 24.7(C-8), 20.6(C-15), 13.2(C-16).

\section{General procedure for the synthesis of compounds $4 a-c$}

The key intermediates $4 \mathbf{a}-\mathbf{c}$ were prepared by the reduction of 3a-c according to literature. ${ }^{28,29}$ Triphenylphosphine (0.85 $\mathrm{mmol})$ was added to the solution of $3 \mathrm{a}-\mathbf{c}(0.71 \mathrm{mmol})$ in THF $(5.0 \mathrm{~mL})$. The solution was stirred at $55^{\circ} \mathrm{C}$ for $2 \mathrm{~h}$. Then, $1.0 \mathrm{~mL}$ of water was added, and stirred at room temperature for about $5 \mathrm{~h}$. After removal of the solvent, $20 \mathrm{~mL}$ of water was added and then extracted with dichloromethane $(3 \times 20 \mathrm{~mL})$. The organic layers were combined, dried over anhydrous $\mathrm{Na}_{2} \mathrm{SO}_{4}$, and concentrated to afford the crude product, which was further purified by silica gel column chromatography (methanol/ dichloromethane, $5: 95, \mathrm{v} / \mathrm{v}$ ) to provide a colorless oil.

2-(10ß-Dihydroartemisinoxy)ethylamine (4a). Colorless oil; yield: $65 \%$; HR-ESI-MS $(\mathrm{m} / \mathrm{z})[\mathrm{M}+\mathrm{H}]^{+}$calcd for: 328.2124 , found: 328.2094; ${ }^{1} \mathrm{H}$ NMR (refer to literature 28$) ;{ }^{13} \mathrm{C}$ NMR $(100 \mathrm{MHz}$, $\left.\mathrm{CDCl}_{3}\right) \delta$ 104.34(C-3), 102.39(C-10), 88.11(C-12), 81.27(C-12a), 71.08(- $\left.\mathrm{OCH}_{2}-\right), \quad 52.76(\mathrm{C}-5 \mathrm{a}), \quad 44.60(\mathrm{C}-8 \mathrm{a}), \quad 42.26\left(-\mathrm{CH}_{2} \mathrm{NH}_{2}\right)$, 37.69(C-6), 36.62(C-4), 34.81(C-7), 31.15(C-9), 26.40(C-14), 24.88(C-5), 24.82(C-8), 20.55(C-15), 13.27(C-16).

3-(10 $\beta$-Dihydroartemisinoxy)propylamine (4b). Colorless oil; yield: $91 \%$; HR-ESI-MS $(\mathrm{m} / \mathrm{z})[\mathrm{M}+\mathrm{H}]^{+}$calcd for: 342.2280 , found: 342.2245; ${ }^{1} \mathrm{H}$ NMR (400 MHz, $\mathrm{CDCl}_{3}$ ) $\delta 5.36$ (s, 1H, H-12), 4.76 (d, $J=3.1 \mathrm{~Hz}, 1 \mathrm{H}, \mathrm{H}-10), 3.96-3.84(\mathrm{dt}, J=10.9,6.0 \mathrm{~Hz}, 1 \mathrm{H}$, $\left.-\mathrm{OCH}_{2}-\right), 3.42\left(\mathrm{dt}, J=10.9,6.0 \mathrm{~Hz}, 1 \mathrm{H},-\mathrm{OCH}_{2}-\right), 2.77(\mathrm{t}, J=$
$6.9 \mathrm{~Hz}, 2 \mathrm{H},-\mathrm{CH}_{2} \mathrm{NH}_{2}$ ), 2.66-2.52 (m, 1H, H-9), $2.34(\mathrm{td}, J=14.0$, $3.7 \mathrm{~Hz}, 1 \mathrm{H}, \mathrm{H}-4), 2.01$ (m, 1H, H-4), 1.86 (m, 1H),1.79-1.66 (m, $4 \mathrm{H}), 1.66-1.60(\mathrm{~m}, 1 \mathrm{H}), 1.53-1.42(\mathrm{~m}, 2 \mathrm{H}), 1.41\left(\mathrm{~s}, 3 \mathrm{H}, \mathrm{CH}_{3}-14\right)$, $1.30(\mathrm{~m}, 1 \mathrm{H}), 1.26-1.16(\mathrm{~m}, 2 \mathrm{H}), 0.92\left(\mathrm{~d}, J=6.1 \mathrm{~Hz}, 3 \mathrm{H}, \mathrm{CH}_{3}-15\right)$, $0.86\left(\mathrm{~d}, J=7.4 \mathrm{~Hz}, 3 \mathrm{H}, \mathrm{CH}_{3}-16\right), 0.86(\mathrm{~m}, 1 \mathrm{H}, \mathrm{H}-7) ;{ }^{13} \mathrm{C} \mathrm{NMR}(100$ $\left.\mathrm{MHz}, \mathrm{CDCl}_{3}\right) \delta 104.3(\mathrm{C}-3), 102.3(\mathrm{C}-10), 88.1(\mathrm{C}-12), 81.3(\mathrm{C}-12 \mathrm{a})$, 66.6(- $\left.\mathrm{OCH}_{2}-\right)$, 52.8(C-5a), 44.6(C-8a), 39.9 $\left(-\mathrm{CH}_{2} \mathrm{NH}_{2}\right), 37.7(\mathrm{C}-$ 6), 36.6(C-4), 34.8(C-7), 33.8 $\left(-\underline{\mathrm{CH}_{2}} \mathrm{CH}_{2} \mathrm{NH}_{2}\right), \quad 31.1(\mathrm{C}-9)$, 26.4(C-14), 24.9(C-5), 24.7(C-8), 20.6(C-15), 13.2(C-16).

6-(10ß-Dihydroartemisinoxy)hexylamine (4c). Colorless oil; yield: $86 \%$; HR-ESI-MS $(\mathrm{m} / \mathrm{z})[\mathrm{M}+\mathrm{H}]^{+}$calcd for: 384.2750 , found: $384.2711 ;{ }^{1} \mathrm{H}$ NMR (400 MHz, $\mathrm{CDCl}_{3}$ ) $\delta 5.34$ (s, 1H, H-12), 4.73 $(\mathrm{d}, J=3.0 \mathrm{~Hz}, 1 \mathrm{H}, \mathrm{H}-10), 3.78\left(\mathrm{dt}, J=15.9,6.6 \mathrm{~Hz}, 1 \mathrm{H},-\mathrm{OCH}_{2}-\right.$ ), $3.41-3.24\left(\mathrm{dt}, J=15.9,6.6 \mathrm{~Hz}, 1 \mathrm{H},-\mathrm{OCH}_{2}-\right), 2.64(\mathrm{t}, J=7.0 \mathrm{~Hz}$, $2 \mathrm{H},-\mathrm{CH}_{2} \mathrm{NH}_{2}$ ), 2.59-2.51 (m, $\left.1 \mathrm{H}, \mathrm{H}-9\right), 2.32(\mathrm{td}, J=14.0,3.7 \mathrm{~Hz}$, 1H, H-4), 1.99 (m, 1H, H-4), 1.91-1.64 (m, 7H), 1.64-1.41 (m, $7 \mathrm{H}), 1.40\left(\mathrm{~s}, 3 \mathrm{H}, \mathrm{CH}_{3}-14\right), 1.38(\mathrm{~m}, 1 \mathrm{H}), 1.29$ (m, 6H), 1.24-1.11 (m, 2H), 0.91 (d, $\left.J=6.2 \mathrm{~Hz}, 3 \mathrm{H}, \mathrm{CH}_{3}-15\right), 0.88$ (m, 1H, H-7), 0.85 $\left(\mathrm{d}, J=7.2 \mathrm{~Hz}, 3 \mathrm{H}, \mathrm{CH}_{3}-16\right) ;{ }^{13} \mathrm{C} \mathrm{NMR}\left(100 \mathrm{MHz}, \mathrm{CDCl}_{3}\right)$ $\delta$ 104.2(C-3), 102.1(C-10), 88.1(C-12), 81.3(C-12a), 68.5(- $\left.\mathrm{OCH}_{2}{ }^{-}\right)$, 52.7(C-5a), 44.7(C-8a), 41.8(- $\left.\mathrm{CH}_{2} \mathrm{NH}_{2}\right), 37.7(\mathrm{C}-6), \quad 36.6(\mathrm{C}-4)$, 34.8(C-7), 32.9( - $\underline{\mathrm{CH}_{2}} \mathrm{CH}_{2} \mathrm{NH}_{2}$ ), 31.1(C-9), 29.8, 26.8, 26.4(C14), 26.3, 24.9(C-5), 24.6(C-8), 20.6(C-15), 13.2(C-16).

\section{General procedure for the synthesis of compounds 5a-c}

The desired compounds 5a-c were prepared according to the literature. $\mathrm{CS}_{2}(47 \mu \mathrm{L}, 0.77 \mathrm{mmol})$ was added dropwise to a solution of compounds $4 \mathrm{a}-\mathrm{c}(0.64 \mathrm{mmol})$ and $\mathrm{Et}_{3} \mathrm{~N}(0.24 \mathrm{~mL}$, $1.9 \mathrm{mmol})$ in anhydrous THF $(5.0 \mathrm{~mL})$ in an ice bath. Then, the solution was stirred for $30 \mathrm{~min}$ at r.t. and $\mathrm{AcCl}(54 \mu \mathrm{L}, 0.77$ $\mathrm{mmol}$ ) was added into the solution at $0{ }^{\circ} \mathrm{C}$. After $5 \mathrm{~min}$ at the same temperature, it was warmed to r.t and stirred for 15$30 \mathrm{~min}$. Then, the reaction was quenched with $2.0 \mathrm{~mL}$ of $5 \%$ $\mathrm{HCl}$ (aq.) and extracted with ethyl acetate three times $(3 \times 10$ $\mathrm{mL}$ ). The organic layers were combined, dried over anhydrous $\mathrm{Na}_{2} \mathrm{SO}_{4}$, and concentrated to afford the crude product, which was purified by silica gel column chromatography (petroleum ether/ethyl acetate $97: 3, \mathrm{v} / \mathrm{v}$ ) to provide 5a-c as a colorless oil.

2-(10ß-Dihydroartemisinoxy)ethyl isothiocyanate (5a). Colorless oil; yield: 49\%; HR-ESI-MS $(\mathrm{m} / \mathrm{z})[\mathrm{M}+\mathrm{H}]^{+}$calcd for: 370.1688, found: $370.1643 ;{ }^{1} \mathrm{H}$ NMR $\left(400 \mathrm{MHz}, \mathrm{CDCl}_{3}\right) \delta 5.43$ (s, $1 \mathrm{H}, \mathrm{H}-12), 4.81$ (d, $J=2.9 \mathrm{~Hz}, 1 \mathrm{H}, \mathrm{H}-10), 4.00(\mathrm{dt}, J=10.3$, $\left.5.1 \mathrm{~Hz}, 1 \mathrm{H},-\mathrm{OCH}_{2}-\right), 3.65\left(\mathrm{t}, J=5.1 \mathrm{~Hz}, 2 \mathrm{H},-\mathrm{CH}_{2} \mathrm{NCS}\right), 3.56(\mathrm{dt}, J$ $\left.=9.7,4.7 \mathrm{~Hz}, 1 \mathrm{H},-\mathrm{OCH}_{2}-\right), 2.69-2.57(\mathrm{~m}, 1 \mathrm{H}, \mathrm{H}-9), 2.33(\mathrm{td}, J=$ 14.1, 3.7 Hz, 1H, H-4), 2.00 (d, $J=14.5 \mathrm{~Hz}, 1 \mathrm{H}, \mathrm{H}-4), 1.90-1.79$ (m, 1H), $1.75(\mathrm{~m}, 2 \mathrm{H}), 1.64(\mathrm{~m}, 1 \mathrm{H}), 1.45(\mathrm{~m}, 3 \mathrm{H}), 1.40(\mathrm{~s}, 3 \mathrm{H}$, $\left.\mathrm{CH}_{3}-14\right), 1.28-1.14(\mathrm{~m}, 2 \mathrm{H}), 0.91\left(\mathrm{~d}, J=6.4 \mathrm{~Hz}, 3 \mathrm{H}, \mathrm{CH}_{3}-15\right), 0.91$ $\left(\mathrm{d}, J=6.4 \mathrm{~Hz}, 3 \mathrm{H}, \mathrm{CH}_{3}-16\right), 0.88-0.79(\mathrm{~m}, 1 \mathrm{H}, \mathrm{H}-7) ;{ }^{13} \mathrm{C} \mathrm{NMR}(100$ $\left.\mathrm{MHz}, \mathrm{CDCl}_{3}\right) \delta 128.99(-\mathrm{N}=\mathrm{C}=\mathrm{S}), 104.35(\mathrm{C}-3), 102.57(\mathrm{C}-10)$, 88.24(C-12), 81.21(C-12a), 66.65(- $\left.\mathrm{OCH}_{2}-\right)$, 52.68(C-5a), 45.65($\left.\mathrm{CH}_{2} \mathrm{NCS}\right), \quad 44.45(\mathrm{C}-8 \mathrm{a}), \quad 37.42(\mathrm{C}-6), \quad 36.55(\mathrm{C}-4), \quad 34.74(\mathrm{C}-7)$, 30.88(C-9), 26.30(C-14), 24.82(C-5), 24.64(C-8), 20.50(C-15), 13.16(C-16).

3-(10ß-Dihydroartemisinoxy)propyl isothiocyanate (5b). Colorless oil; yield: 53\%; HR-ESI-MS $(\mathrm{m} / \mathrm{z})[\mathrm{M}+\mathrm{H}]^{+}$calcd for: 
384.1845, found: 384.1802; ${ }^{1} \mathrm{H}$ NMR (400 MHz, $\left.\mathrm{CDCl}_{3}\right) \delta 5.36(\mathrm{~s}$, $1 \mathrm{H}, \mathrm{H}-12$ ), 4.78 (d, $J=3.2 \mathrm{~Hz}, 1 \mathrm{H}, \mathrm{H}-10), 4.02-3.88$ (dt, $J=9.5$, $\left.6.4 \mathrm{~Hz}, 1 \mathrm{H},-\mathrm{OCH}_{2}-\right), 3.60\left(\mathrm{t}, J=6.6 \mathrm{~Hz}, 2 \mathrm{H},-\mathrm{CH}_{2} \mathrm{NCS}\right), 3.53-$ $3.41\left(\mathrm{dt}, J=9.5,6.4 \mathrm{~Hz}, 1 \mathrm{H},-\mathrm{OCH}_{2}-\right), 2.70-2.57$ (m, $\left.1 \mathrm{H}, \mathrm{H}-9\right)$, $2.35(\mathrm{td}, J=14.1,3.8 \mathrm{~Hz}, 1 \mathrm{H}, \mathrm{H}-4), 2.01$ (m, 1H, H-4), 1.97$1.91(\mathrm{~m}, 2 \mathrm{H}), 1.87(\mathrm{~m}, 1 \mathrm{H}), 1.81-1.67(\mathrm{~m}, 2 \mathrm{H}), 1.63(\mathrm{~m}, 2 \mathrm{H}), 1.49$ $(\mathrm{m}, 2 \mathrm{H}), 1.42\left(\mathrm{~s}, 3 \mathrm{H}, \mathrm{CH}_{3}-14\right), 0.94\left(\mathrm{~d}, J=6.3 \mathrm{~Hz}, 3 \mathrm{H}, \mathrm{CH}_{3}-15\right)$, 0.89 (d, $\left.J=7.3 \mathrm{~Hz}, 3 \mathrm{H}, \mathrm{CH}_{3}-16\right), 0.87-0.80(\mathrm{~m}, 1 \mathrm{H}, \mathrm{H}-7) ;{ }^{13} \mathrm{C}$ NMR $\left(100 \mathrm{MHz}, \mathrm{CDCl}_{3}\right) \delta 129.5(-\mathrm{N}=\mathrm{C}=\mathrm{S}), 104.4(\mathrm{C}-3), 102.4(\mathrm{C}-$ 10), 88.1(C-12), 81.2(C-12a), 64.8(- $\left.\mathrm{OCH}_{2}-\right), 52.8(\mathrm{C}-5 \mathrm{a}), 44.5(\mathrm{C}-$ 8a), 42.5(- $\left.\mathrm{CH}_{2} \mathrm{NCS}\right), 37.7(\mathrm{C}-6), 36.6(\mathrm{C}-4), 34.8(\mathrm{C}-7), 31.0(\mathrm{C}-9)$, $30.3\left(-\underline{\mathrm{CH}_{2}} \mathrm{CH}_{2} \mathrm{NCS}\right)$ 26.4(C-14), 24.9(C-5), 24.8(C-8), 20.5(C-

15), 13.2(C-16).

6-(10ß-Dihydroartemisinoxy)hexyl isothiocyanate (5c). Colorless oil; yield: 76\%; HR-ESI-MS $(\mathrm{m} / \mathrm{z})[\mathrm{M}+\mathrm{H}]^{+}$calcd for: 426.2314, found: $426.2302 ;{ }^{1} \mathrm{H} \mathrm{NMR}\left(400 \mathrm{MHz}, \mathrm{CDCl}_{3}\right) \delta 5.35$ (s, 1H, H-12), $4.74(\mathrm{~d}, J=3.2 \mathrm{~Hz}, 1 \mathrm{H}, \mathrm{H}-10), 3.80\left(\mathrm{dt}, J=9.5,6.4 \mathrm{~Hz}, 1 \mathrm{H},-\mathrm{OCH}_{2}-\right.$ ), $3.48\left(\mathrm{t}, J=6.6 \mathrm{~Hz}, 2 \mathrm{H},-\mathrm{CH}_{2} \mathrm{NCS}\right), 3.33(\mathrm{dt}, J=9.5,6.4 \mathrm{~Hz}, 1 \mathrm{H}$, $-\mathrm{OCH}_{2}{ }^{-}$), 2.65-2.47 (m, 1H, H-9), 2.33 (td, $J=14.0,3.8 \mathrm{~Hz}, 1 \mathrm{H}, \mathrm{H}-$ 4), 2.06-1.94 (m, 1H, H-4), 1.92-1.80 (m, 1H), 1.80-1.70 (m, 2H), 1.70-1.61 (m, 3H), $1.53(\mathrm{~m}, 4 \mathrm{H}), 1.41\left(\mathrm{~s}, 3 \mathrm{H}, \mathrm{CH}_{3}-14\right), 1.35(\mathrm{~m}$, $3 \mathrm{H}), 1.20(\mathrm{~m}, 2 \mathrm{H}), 0.92\left(\mathrm{~d}, J=6.2 \mathrm{~Hz}, 3 \mathrm{H}, \mathrm{CH}_{3}-15\right), 0.89(\mathrm{~m}, 1 \mathrm{H}, \mathrm{H}-$ 7), $0.86\left(\mathrm{~d}, J=7.2 \mathrm{~Hz}, 3 \mathrm{H}, \mathrm{CH}_{3}-16\right) ;{ }^{13} \mathrm{C} \mathrm{NMR}\left(100 \mathrm{MHz}, \mathrm{CDCl}_{3}\right)$ $\delta$ 129.8 $(-\mathrm{N}=\mathrm{C}=\mathrm{S}), 104.2(\mathrm{C}-3), 102.2(\mathrm{C}-10), 88.1(\mathrm{C}-12)$, 81.3(C12a), 68.4(- $\left.\mathrm{OCH}_{2}-\right), \quad 52.7(\mathrm{C}-5 \mathrm{a}), \quad 45.2\left(-\mathrm{CH}_{2} \mathrm{NCS}\right), \quad 44.6(\mathrm{C}-8 \mathrm{a})$, 37.7(C-6), 36.6(C-4), 34.8(C-7), 31.1(C-9), 30.1, 29.6, 26.5, 26.4(C14), 25.7, 24.9(C-5), 24.7(C-8), 20.6(C-15), 13.2(C-16).

\section{Cell lines and reagents}

In the present study, a U87 cell line (from Prof. Wenbo Zhu, Zhongshan Medical School, Sun Yat-sen University) was used. The cells were maintained in Dulbecco's modified Eagle's medium (Gibo; Thermo Scientific, China) supplemented with $10 \%$ fetal bovine serum (PAN BIOTECH) in a humidified incubator at $37{ }^{\circ} \mathrm{C}$ with $5 \% \mathrm{CO}_{2}$. Artemisinin-based isothiocyanate derivatives were dissolved in dimethyl sulfoxide and stored at $-20{ }^{\circ} \mathrm{C}$ in the dark. Annexin V-FITC apoptosis detection kits were from Best Bio(China). The antibodies used are listed in Table 2 .

\section{Cytotoxic assay}

The cells were seeded in 96-well plates at a density of $1 \times 10^{4}$ cells $/ 100 \mu \mathrm{L}$ and treated with different concentrations of the compounds ranging from 1 to $250 \mu \mathrm{M}$. After 24 hours of incubation, MTT (Sigma-Aldrich) was added to cells following the treatment and incubated for $4 \mathrm{~h}$ at $37{ }^{\circ} \mathrm{C}$. DMSO was subsequently added, and the absorbance was measured with a microplate reader after shaking for $\sim 30 \mathrm{~s}$. The half maximal inhibitory concentration $\left(\mathrm{IC}_{50}\right)$ was calculated. The cytotoxicity of $5 \mathbf{b}$ and DHA were investigated for the 24 and $72 \mathrm{~h}$ incubations.

\section{Wound healing assay}

The wound healing assay was performed in 6-well tissue culture plates. After the cells were allowed to attach and reach $80 \%$ confluence, a scratch in the cell monolayer was made using a sterilized pipette tip $(10 \mu \mathrm{L})$. Thereafter, all wound-healing processes were performed in serum-free conditions. After washing with $0.01 \mathrm{M}$ phosphate-buffered saline (PBS, $\mathrm{pH} 7.4$ ), the plates were incubated with $\mathbf{5 b}$ or with DMSO, and images were captured at $0,24,48$ and $72 \mathrm{~h}$ using an EVOS ${ }^{\circledR}$ Digital microscope. Cell death would affect the wound healing results. Thus, to avoid too much cell death, half of the $\mathrm{IC}_{50}(4 \mu \mathrm{M})$ of $5 \mathbf{b}$ was used. The distance of wound healing was calculated with the MRI wound healing tool of the Image J software (National Institutes of Health, MD, USA).

\section{DAPI staining}

Morphological changes of the nuclear chromatin of apoptotic cells were identified by staining with the DNA binding dye $4^{\prime}$, 6diamidino-2-phenylindole (DAPI, cat. no. D8417, Sigma Aldrich). Cells were grown in 12-well plates at a density of $1 \times$ $10^{5}$ cells per well followed by the desired treatment. After $16 \mathrm{~h}$ of incubation, the cells were washed with cold PBS, fixed with $4 \%$ paraformaldehyde for $30 \mathrm{~min}$ at room temperature, rewashed and then stained with DAPI solution $\left(1\right.$ : 1000in PBS) at $37^{\circ} \mathrm{C}$ for $5 \mathrm{~min}$. After removing the staining solution, apoptotic cells were visualized using a fluorescence microscope.

\section{Apoptotic analysis by flow cytometry}

For this assay, U87 cancer cells were seeded at a density of $2 \times$ $10^{6}$ cells per $\mathrm{mL}$ and then incubated with 0,8 and $16 \mu \mathrm{M}$ of $5 \mathbf{b}$ for $16 \mathrm{~h}$. The cells were harvested using trypsinization and then washed with ice-cold PBS and resuspended in binding buffer. After adding Annexin V-FITC and PI, the cells were incubated at $4{ }^{\circ} \mathrm{C}$ in the dark for 15 minutes according to the manufacturer instructions. The samples were analyzed by flow cytometer (Beckman Coulter, Epics XL) for the percentage of apoptotic and necrotic cells.

\section{Western blot assay}

Treated cells were washed with cold PBS and lysed in a radioimmunoprecipitation assay (RIPA) buffer supplemented with a proteinase inhibitor for extracting total proteins. Protein concentrations were determined by the bicinchoninic acid (BCA) protein assay. After denaturation, the proteins were separated in SDS polyacrylamide gel electrophoresis and transferred onto PVDF membranes. Nonspecific binding was blocked with $5 \%$ milk in TBST buffer for $2 \mathrm{~h}$, followed by incubation with primary antibodies at $4{ }^{\circ} \mathrm{C}$ overnight and secondary antibodies at room temperature for $2 \mathrm{~h}$. Blots were visualized using ECL detection reagents.

\section{Conflicts of interest}

There are no conflicts to declare.

\section{Acknowledgements}

This study was supported by the Guangdong Provincial International Cooperation Project of Science \& Technology (No. 
2013B051000038), the National Natural Science Foundation of China (No. 31371070, No. 81671264), Grant (No. 201704020222, No. 201807010094) from Guangzhou Science, Technology and Innovation Commission and the Fundamental Research Funds for the Central Universities (No. 15ykjc08b) to R. Pi., the Science and Technology Project of Guangzhou City (201607010293) to X. He, (2014Y2-00500) to M. Li. The authors also thank the Talented Young Scientist Program supported by the China Science and Technology Exchange Center for the fellowship.

\section{Notes and references}

1 R. Stupp, W. P. Mason, M. J. van den Bent, M. Weller, B. Fisher, M. J. Taphoorn, K. Belanger, A. A. Brandes, C. Marosi, U. Bogdahn, J. Curschmann, R. C. Janzer, S. K. Ludwin, T. Gorlia, A. Allgeier, D. Lacombe, J. G. Cairncross, E. Eisenhauer and R. O. Mirimanoff, $N$. Engl. J. Med., 2005, 352, 987-996.

2 J. P. Thakkar, T. A. Dolecek, C. Horbinski, Q. T. Ostrom, D. D. Lightner, J. S. Barnholtz-Sloan and J. L. Villano, Cancer Epidemiol., Biomarkers Prev., 2014, 23, 1985-1996.

3 M. A. van Agtmael, T. A. Eggelte and C. J. van Boxtel, Trends Pharmacol. Sci., 1999, 20, 199-205.

4 L. Gang, S. Song, X. Liu, A. Zhang, Z. Miao and C. Ding, RSC Adv., 2016, 6, 98975-98984.

5 N. H. Zuma, F. J. Smit, C. de Kock, J. Combrinck, P. J. Smith and D. D. N'Da, Eur. J. Med. Chem., 2016, 122, 635-646.

6 Z. S. Zhang, J. Wang, Y. B. Shen, C. C. Guo, K. E. Sai, F. R. Chen, X. Mei, F. U. Han and Z. P. Chen, Oncol. Lett., 2015, 10, 379-383.

7 C. Qu, J. Ma, X. Liu, Y. Xue, J. Zheng, L. Liu, J. Liu, Z. Li, L. Zhang and Y. Liu, Front. Cell. Neurosci., 2017, 11, 310.

8 Y. K. Wong, C. Xu, K. A. Kalesh, Y. He, Q. Lin, W. S. F. Wong, H. M. Shen and J. Wang, Med. Res. Rev., 2017, 37, 1492-1517.

9 X. Wu, Q. H. Zhou and K. Xu, Acta Pharmacol. Sin., 2009, 30, 501-512.

10 M. L. Abba, N. Patil, J. H. Leupold, M. E. M. Saeed, T. Efferth and H. Allgayer, Cancer Lett., 2018, 429, 11-18.

11 Y. Zhang, G. Xu, S. Zhang, D. Wang, P. Saravana Prabha and Z. Zuo, Nat. Prod. Bioprospect., 2018, 8, 303-319.

12 J. W. Fahey, A. T. Zalcmann and P. Talalay, Phytochemistry, 2001, 56, 5-51.

13 N. K. Amaglo, R. N. Bennett, R. B. L. Curto, E. A. Rosa, V. L. Turco, A. Giuffrida, A. L. Curto, F. Crea and G. M. Timpo, Food Chem., 2010, 122, 1047-1054.

14 C. Müller, J. Van Loon, S. Ruschioni, G. R. De Nicola, C. E. Olsen, R. Iori and N. Agerbirk, Phytochemistry, 2015, 118, 139-148.

15 S. M. Lewis, Y. Li, M. J. Catalano, A. R. Laciak, H. Singh, D. R. Seiner, T. J. Reilly, J. J. Tanner and K. S. Gates, Bioorg. Med. Chem. Lett., 2015, 25, 4549-4552.
16 Y. J. Jeong, H. J. Cho, F. L. Chung, X. Wang, H. S. Hoe, K. K. Park, C. H. Kim, H. W. Chang, S. R. Lee and Y. C. Chang, Oncotarget, 2017, 8, 63949-63962.

17 Y. T. Yang, Y. Shi, M. Jay and A. J. Di Pasqua, Chem. Res. Toxicol., 2014, 27, 946-948.

18 T. S. Rajan, G. R. De Nicola, R. Iori, P. Rollin, P. Bramanti and E. Mazzon, Fitoterapia, 2016, 110, 1-7.

19 K. C. Liu, T. Y. Shih, C. L. Kuo, Y. S. Ma, J. L. Yang, P. P. Wu, Y. P. Huang, K. C. Lai and J. G. Chung, Am. J. Chin. Med., 2016, 44, 1289-1310.

20 R. K. Singh, T. S. Lange, K. Kim, Y. Zou, C. Lieb, G. L. Sholler and L. Brard, Bioorg. Med. Chem. Lett., 2007, 17, 5846-5852.

21 P. Sestili and C. Fimognari, BioMed Res. Int., 2015, 2015, 402386.

22 R. Grzywa, Ł. Winiarski, M. Psurski, A. Rudnicka, J. Wietrzyk, T. Gajda and J. Oleksyszyn, Bioorg. Med. Chem. Lett., 2016, 26, 667-671.

23 A. Minarini, A. Milelli, C. Fimognari, E. Simoni, E. Turrini and V. Tumiatti, Expert Opin. Drug Metab. Toxicol., 2014, 10, 25-38.

24 V. Citi, A. Martelli, L. Testai, A. Marino, M. C. Breschi and V. Calderone, Planta Med., 2014, 80, 610-613.

25 L. D. C. Mannelli, E. Lucarini, L. Micheli, I. Mosca, P. Ambrosino, M. V. Soldovieri, A. Martelli, L. Testai, M. Taglialatela, V. Calderone and C. Ghelardini, Neuropharmacology, 2017, 121, 49-59.

26 S. Huang, J. H. Chua, W. S. Yew, J. Sivaraman, P. K. Moore, C. H. Tan and L. W. Deng, J. Mol. Biol., 2010, 396, 708-718. 27 Z. Ma, Q. Bi and Y. Wang, Oral Dis., 2015, 21, 156-162.

28 Y. Liu, Z. Liu, J. Shi, H. Chen, B. Mi, P. Li and P. Gong, Molecules, 2013, 18, 2864-2877.

29 Y. Tian, Z. Liang, H. Xu, Y. Mou and C. Guo, Molecules, 2016, 21, 758.

30 J. M. Wu, F. Shan, G. S. Wu, Y. Li, J. Ding, D. Xiao, J. X. Han, G. Atassi, S. Leonce, D. H. Caignard and P. Renard, Eur. J. Med. Chem., 2001, 36, 469-479.

31 B. Luo, J. Wang, X. Li, W. Lu, J. Yang, Y. Hu, P. Huang and S. Wen, Molecules, 2017, 22, 773.

32 A. K. Pathak, D. U. Jain and R. F. Sharma, Indian J. Chem., Sect. B: Org. Chem. Incl. Med. Chem., 1995, 34B, 992-993.

33 A. R. Butler, L. Conforti, P. Hulme, L. M. Renton and T. J. Rutherford, J. Chem. Soc., Perkin Trans. 1, 1999, 2, 2089-2092.

34 A. Grada, M. Otero-Vinas, F. Prieto-Castrillo, Z. Obagi and V. Falanga, J. Invest. Dermatol., 2017, 137, e11-e16.

35 L. Jia, Q. Song, C. Zhou, X. Li, L. Pi, X. Ma, H. Li, X. Lu and Y. Shen, PLoS One, 2016, 11, e0147157.

36 S. Elmore, Toxicol. Pathol., 2007, 35, 495-516.

37 N. Morishima, K. Nakanishi, H. Takenouchi, T. Shibata and Y. Yasuhiko, J. Biol. Chem., 2002, 277, 34287-34294.

38 A. M. Schläfli, S. Berezowska, O. Adams, R. Langer and M. P. Tschan, Eur. J. Histochem., 2015, 59, 2481. 